\title{
Treatment of proximal femoral fractures
}

\author{
G Gasparini", B lannò, F Di Luggo, A Cundari \\ From de Senectute: Age and Health Forum \\ Catanzaro, Italy. 5-7 December 2009
}

Femoral fractures have to be considered frequent causes of hospital admission for the elderly. These fractures are characterized by an uncertain prognosis in terms of both morbidity and mortality. The management of proximal femoral fractures in the elderly should be multidisciplinary, indeed the fall causing the fracture might follow a neurological, metabolic or cardiovascular disorder. Thus the treatment of the hidden disease is mandatory prior to fixing the fracture. Furthermore any unknown disease could significantly affect the health status of the patient increasing the operative risk. At admission to hospital accurate case history and physical examination have to be recorded. These fractures have to be surgically treated whenever it is possible. Indeed, the conservative treatment is a burden with a lot of complications. The early surgical treatment (within 24 hours from the injury) is effective to reduce complications and mortality. When choosing the appropriate surgical treatment, a preliminary distinction among the medial fractures (subcapital and transcervical) and the lateral ones (basal, intertrochanteric, subtrochanteric) is done. Medial fractures usually cause the interruption of the lateral epihisary blood vessels with consequent avascular necrosis of the femoral head thus requiring a hemi- or total arthroplasty. Lateral injuries should be treated preferably by reduction and internal fixation. The latter fractures may in turn be divided into two subgroups on the basis of integrity of the medial femoral region near the lesser trochanter (stable or unstable fractures). Stable fractures can be fixed with a dynamic hip screw, whereas unstable fractures are usually treated by means of a proximal femoral nail.

Early surgical treatment allows resumption of walking, and a sudden recovery of the patient's autonomy. However the mortality rate of patients with proximal femoral

Clinica Ortopedica. Università degli Studi Magna Graecia. Catanzaro, Italy fracture is higher than the mortality rate of an age and sex-matched population.

Published: 19 May 2010

doi:10.1186/1471-2318-10-S1-L10

Cite this article as: Gasparini et al.: Treatment of proximal femoral fractures. BMC Geriatrics 2010 10(Suppl 1):L10.
Submit your next manuscript to BioMed Central and take full advantage of:

- Convenient online submission

- Thorough peer review

- No space constraints or color figure charges

- Immediate publication on acceptance

- Inclusion in PubMed, CAS, Scopus and Google Scholar

- Research which is freely available for redistribution

Submit your manuscript at www.biomedcentral.com/submit
C Biomed Central 